\title{
GC-MS Analysis of Phytochemical Constituents in Methanol Extract of Wood Bark from Durio Zibethinus Murr
}

\author{
Adeniyi S Adegoke ${ }^{1^{*}}$, Oke V Jerry ${ }^{1}$, Olatunji G Ademola ${ }^{2}$ \\ ${ }^{1}$ Department of Chemistry, College of Natural and Applied Sciences, Igbinedion University Okada, \\ Edo State, Nigeria. \\ ${ }^{2}$ Department of Chemistry, University of Ilorin, Ilorin, Kwara State, Nigeria.
}

\begin{abstract}
*Corresponding Author: Adeniyi S Adegoke, Department of Chemistry, College of Natural and Applied Sciences, Igbinedion University Okada, Edo State, Nigeria.
\end{abstract}

\begin{abstract}
Durio zibethinus Murr. (Durian), a medicinally important plant belongs to the family Bombacaceae. Traditionally the decoctions of the leaf and root have believed to show antipyretic effect and can also be used as a febrifuge and anti-malarial agent. In the present study, the preliminary phytochemical screening of secondary metabolites in the wood bark of Durio zibethinus was investigated using standard methods. The methanol extract of the wood bark was fractionated into four combined fractions (F1- F4) and the bioactive compounds in the fractions were evaluated using Gas Chromatography-Mass Spectrometry. Phytochemical screening on this crude extract revealed the presence of phenols, alkaloids, steroids, tannins, terpenes, saponins and flavonoids. Gas chromatography-mass spectrometry (GC-MS) analysis revealed the presence of 2, 6, 5 and 4 compounds in fractions 1-4 respectively. The major chemical constituents identified are (Z)-9-Octadecenoic acid (Oleic Acid) (91.36 \%), (E)-9-Octadecenoic acid (Elaidic Acid) (56.10\%), (Z)6-Octadecenoic acid (Petroselinic acid) (41.19\%) and (E)-9-Octadecenoic acid (Elaidic Acid) (42.20\%) in fractions 1-4 respectively. The presence of these major constituents in the plant extract provides the scientific evidences for its biological and therapeutic properties related to health. Thus this research was aimed to investigate the secondary metabolites present in the wood bark of Durio zibethinus Murr that could have medicinal values and application in industries, as well as, to identify the phytoconstituents by using GC-MS analysis.
\end{abstract}

Keywords: Durio zibethinus Murr.; Phytochemical screening; Secondary metabolites; GC-MS

\section{INTRODUCTION}

Medicinal plants and herbs have been proved to be of great importance to the health of the individuals and Communities (Alves et al., 2000). The evaluation of all the drugs is based on phytochemical and pharmacological approaches which leads to the drug discovery referred as natural product screening (Foye et al., 2008). Any part of the plant may contain active components such as bark, leaves, flowers, roots, fruits and seeds (Gordon and David. 2001). Phytochemicals are the chemicals produced by various parts of the plants. These bioactive compounds have various activities such as antimicrobial and antibacterial some have been reported to exhibit hemolytic and foaming activity reported by Sanjeeb et al. (2011).

Durian (Durio zibethinus Murr.; Family Bombacaceae) is a tropical fruit plant cultivated in Malaysia and the Southeast Asian countries (Bhore et al., 2018). Durian is considered as "King of Tropical Fruit" due to its high nutritional status and with its appearance that resembles the thorny thrones of Asian kings (Subhadrabandhu and Ketsa, 2001). Scientific interest lies in the fact that durian is considered by some botanists to be one of the most primitive of the trees in the tropical rain forest (Bautista et al., 2012). Fruit pulp of this fruit is an excellent source of nutrients as it contains proteins, dietary fat, fibers, and carbohydrates (Bhore et al., 2018).

The durian fruit is believed to have warming properties on the body; however, it has not been clinically investigated (Brown, 1997). Durian fruit is considered to have potential medicinal and therapeutic properties that include its ability to boost the immune system and wound healing (Chansiripornchai and Pongsamart, 2008). It is also widely believed that durian pulp contains strong 
aphrodisiac properties and local community believes that consumption of fruits in conjunction with alcohol will lead to death. However, there is no evidence to support these claims (Ho and Bhat, 2015). It is reported that durian has anti-oxidant (Ang, 2018), anti-cancer, anti-cardiovascular, anti-diabetic (Leontowicz et al., 2007; Siburian et al., 2019) and anti-obesity properties (Leontowicz et al., 2008), and can improve digestion, cure insomnia, lower the blood pressure and relieve the symptoms of depression, anxiety, and stress disorders (Kumar et al., 2005; Haruenkit et al., 2007). Previous studies have also reported the potential use of durian fruit pulp as fertility enhancing agent and studies were conducted to find out its effectiveness to treat infertility in PCOS (polycystic ovarian syndrome) (Ansari, 2016). Although the fruit is effective against various components of metabolic syndrome, specific studies of the mechanism of ovulation and menstrual disturbances need to be conducted. Durian fruits have also shown anti-proliferative activities as being reported by Jalil and Aziz (2019). With this background, the present study was aimed to investigate the secondary metabolites present in the wood bark of Durio zibethinus Murr. which have medicinal values and application in industries, as well as, to identify the phytoconstituents by using GC-MS analysis.

\section{MATERIALS AND METHODS}

\subsection{Plant Collection and Identification}

Fresh plant materials of Durio zibethinus Murr., were collected from the premises of Igbinedion University, Okada in Ovia North-East Local Government Area of Edo State, Nigeria. The plant materials were identified by the herbarium curator of Department of Plant Biology, University of Ilorin and authenticated by comparing it with authentic specimen at the Botanical Survey of India, Coimbatore with Voucher No. UILH/001/1371.

\subsection{Plant Preparation}

The plant materials were thoroughly washed with distilled water, chopped into smaller pieces to increase the surface area of the parts to allow for a quicker drying period and air-dried at room temperature $\left(26^{\circ} \mathrm{C}\right)$ for 12 weeks. An electrical grinder was used to grind the dried material into fine powders. During the course of this study, the powdered plant material was stored in air-tight glass containers and kept away from sunlight to prevent possible photo-oxidation reactions.

\subsection{Qualitative Phytochemical Screening}

Qualitative phytochemical screening of the extract was carried out for various plant constituents. The crude extract was screened for the presence or absence of secondary metabolites such as alkaloids, saponins, tannins, flavonoids, steroids, terpenoids, cardiac glycosides and phenolic compounds using standard procedures with minor modifications where necessary.

\subsubsection{Detection of Alkaloids}

A $100 \mathrm{mg}$ of each stem bark extract was diluted with $5 \mathrm{ml}$ of hydrochloric acid, boiled and filtered. To $2 \mathrm{ml}$ of the filtrate was added to $1 \mathrm{ml}$ of dilute ammonia. $2 \mathrm{ml}$ of chloroform was added and shaken gently to extract the alkaloidal base. The chloroform layer was extracted with $5 \mathrm{ml}$ of acetic acid. This was divided into two portions. Mayer's reagent was added to one portion and Draggendoff's reagent to the other. The formation of a cream (with Mayer's reagent) or reddish brown precipitate (with Draggendoff's reagent) was regarded as positive for the presence of alkaloids (Ejikeme et al., 2017).

\subsubsection{Detection of Saponins}

Froth test: $0.5 \mathrm{~g}$ of each stem bark extract dissolved in $10 \mathrm{ml}$ of distilled water in a test tube, stoppered, shaken vigorously for about 20 seconds, allowed to stand in a vertical position and observed over a 30 minute period of time for a "honey comb" froth above the surface of liquid after 30 min shall be taken as a positive test for the presence of saponins (Ejikeme et al., 2014).

\subsubsection{Detection of Tannins}

Ferric chloride test: A portion of each stem bark extract dissolved in distilled water and clarified by filtration. A bluish black colouration after the addition of $10 \%$ ferric chloride solution indicated the presence of tannins (Santhi and Sengottuvel, 2016).

\subsubsection{Detection of Flavonoids}

$0.5 \mathrm{~g}$ of each stem bark extract was dissolved in diluted $\mathrm{NaOH}$ and $\mathrm{HCl}$ was added. A yellow solution that turned colourless indicated the presence of flavonoids (Gothandam et al., 2010). 


\subsubsection{Detection of Steroidal Compounds}

Lieberman's test: $0.5 \mathrm{~g}$ of each stem bark extract was dissolved in $2 \mathrm{ml}$ of acetic anhydride and cooled well in an ice-bath. A colour changed from purple to blue to green when concentrated sulphuric acid was carefully added, indicating the presence of a steroid nucleus (Seema and Parwez, 2011).

\subsubsection{Detection of Terpenoids}

Salkowski's test: $0.5 \mathrm{~g}$ of each stem bark extract was dissolved in $2 \mathrm{ml}$ of chloroform. Concentrated $\mathrm{H}_{2} \mathrm{SO}_{4}(3 \mathrm{ml})$ was carefully added to form a layer. A reddish brown colouration at the interface indicated the presence of terpenoids (Rahman et al., 2017).

\subsubsection{Detection of Cardiac Glycosides}

Keller-Killiani's test: $0.5 \mathrm{~g}$ of each stem bark was dissolved in water and $2 \mathrm{ml}$ of glacial acetic acid containing one drop of ferric chloride solution was added. $1 \mathrm{ml}$ of concentrated sulphuric acid was carefully added to form a brown ring at the interface indicating the presence of Deoxysugar characteristic of Cardenolides. A violet ring will appear below the brown ring, while in the acetic acid layer a greenish ring will form just above the brown ring and gradually spread throughout this layer (Aiyelaagbe and Osamudiamen, 2009).

\subsubsection{Detection of Phenolic Compounds}

Each stem bark extract was dissolved in distilled water, and a few drops of $1 \%$ lead acetate were added to form a bulky white precipitate which indicated the presence of phenolic compounds (Prabhavathi et al., 2016).

\subsection{GC-MS Analysis}

\subsubsection{Instruments and Chromatographic Conditions}

The GC-MS analysis was performed on an Agilent Technologies interfaced [Model: 7890A (GC)] with Mass Selective Detector model: 5975C (MSD). The electron ionization was at a 70v with an ion source temperature at $250{ }^{\circ} \mathrm{C}$. Highly pure helium gas (99.9\% purity) was used as carrier gas, while HP- $5 \mathrm{~ms}(30 \mathrm{~mm} \times 0.25 \mathrm{~mm} \times 0.320 \mu \mathrm{m})$ was used as the stationary phase. The oven temperature program initial temperature is $140{ }^{\circ} \mathrm{C}$ held for 5 minutes at $4^{\circ} \mathrm{C}$ per minute to the final temperature of $240{ }^{\circ} \mathrm{C}$ to hold for 15 minute at the rate of $3.5^{\circ} \mathrm{C} /$ minutes holding for 6 minutes. $1 \mu / 1$ of each fraction of the methanolic extract of wood bark from D. zibethinus was auto injected.

\subsubsection{Identification of Phytochemical Compounds}

Identification of phytochemical compounds and interpretation on mass spectrum GC-MS was conducted using the database of National Institute Standard and Technology (NIST) having more than 62,000 patterns. The spectrum of the unknown component was compared with the spectrum of the known components using computer searches on a NIST Ver.2.1 MS data library. The name, molecular weight and structure of the components of the test materials were established.

\section{RESULTS AND DISCUSSION}

\subsection{Qualitative Phytochemical Screening}

Qualitative determination of phytochemicals as seen in Table 1 showed various plant secondary metabolites in which there was presence of alkaloids, saponins, tannins, flavonoids, terpenoids, glycosides and phenolic compounds, while steroids were found to be absent in wood bark of $D$. zibethinus.

Plants have been shown to contain secondary metabolites that can also protect humans against diseases (Doughari et al., 2009). To these effects most of the phytochemicals have been reported by several authors for specific functions. For instance, Agu and Thomas (2012) reported that alkaloids have defense mechanisms through which plants ward off pests. This suggests the medicinal properties (such as analgesic, antispasmodic and bactericidal effects) of alkaloids from plants (Kigigha et al., 2015; Epidi et al., 2016; Doherty et al., 2010; Osuntokun and Oluwafoise, 2015). Alkaloids are also essential for the treatment of cardiovascular and kidney disorders (Sweetman, 2005). It was also reported that alkaloids have a wide range of pharmacological activities including antimalarial (e.g., 
quinine), anticancer (e.g., homoharringtonine) (Kittakoop et al.,2014), antibacterial (e.g., chelerythrine) (Cushnie et al., 2014), and antihyperglycemic activities (e.g., piperine) (Qiu et al., 2014).

Saponins in the wood bark is an indication that the plant could be used as expectorant, cough suppressant and it also has hemolytic activity (Kigigha et al., 2015; Okwu, 2005; Osuntokun and Oluwafoise, 2015; Epidi et al., 2016). Saponins have been reported to have antimicrobial (Soetan et al., 2006), antifungal (Hazem et al., 2012) and anti-inflammatory properties (Patel and Patil, 2012). Brusotti et al. (2013) also reported that saponin has been demonstrated to be a good candidate for the control of a pathogen of rice blast disease, Pyricularia grisea.

Tannins are known to occur abundantly in the bark of trees where they act as a barrier to microorganisms. Tannin is astringent in nature and has the ability to bind or precipitate proteins and various other organic compounds making them unavailable for absorption. Plants rich in Tannin are said to have several medical applications (Okuda, 2005; Doughari et al, 2009). Tannins have health importance such as wound healing, varicose ulcers, hemorrhoids, frostbite and burns, and it has the ability to regenerate skin, as well as anti-inflammatory and anti-diuretics activity (Okwu and Okwu, 2004; Khanbabaee and van Ree, 2001).

TABLE1. Qualitative phytochemical screening of methanolic extract of wood bark from Durio zibethinus

\begin{tabular}{|l|l|}
\hline Secondary Metabolites & Stem bark \\
\hline Alkaloids & + \\
\hline Saponins & + \\
\hline Tannins & + \\
\hline Flavonoids & + \\
\hline Steroids & - \\
\hline Terpenoids & + \\
\hline Glycosides & + \\
\hline Phenolic compounds & + \\
\hline
\end{tabular}

Key: Present: +; Absent: - .

Flavonoids have been reported to possess antioxidant, anticarcinogenic, antimicrobial antitumor, allergenic, anti-inflammatory and antidiarrheal properties (Yamamoto and Gaynor 2001; Cushnie and Lamb 2005; Chahar et al., 2011; Yao et al., 2011). Flavonoids are also essential for the treatment of ulcer (Ateufack et al., 2015).

Naturally occurring terpenoids often exhibit a variety of biological activities such as antiinflammatory, anti-HIV, anti-tumour-promoting, ichthyotoxic and antimycobacterial activities (Cantrell et al., 2001; Rajic et al., 2000; Villar et al.,2003).

Reports have confirmed the antiproliferative and apoptotic effects of cardiac glycosides in several cancer cell lines, including breast (Kometiani et al., 2005; Bielawski et al., 2006; Lopez-Lazaro et al., 2005), prostate (McConkey et al., 2000; Huang et al., 2004; Yeh et al., 2003), melanoma (Newman et al., 2006), pancreatic (Newman et al., 2007), lung (Mijatovic et al., 2006; Frese et al., 2006), leukaemia (Raghavendra et al., 2007; Daniel et al., 2003) and renal adenocarcinoma (Lopez-Lazaro et al., 2005)78. Cardiac glycosides have been a cornerstone of the treatment of heart diseases (Ahmed $e t$ al., 2008). Phenols have been reported to possess antioxidant (Heima et al., 2002), antibacterial and antifungal (Alasalvar et al., 2001; Acamovic and Brooker, 2005; Edreva et al., 2008). All these facts may be linked to the biological activities of wood bark from $D$. zibethinus.

\subsection{GC-MS Analysis}

GC-MS is one of the best techniques to identify the constituents of volatile matter, long chain, branched chain hydrocarbons, alcohols acids, esters etc. The GC-MS analysis of fractions of $D$. zibethinus wood bark revealed the presence of two, six, five and four compounds (phytochemical constituents) in fractions $1,2,3$, and 4 respectively. The peaks in the chromatogram were integrated and compared with the database of spectrum of known components stored in the GC-MS library. The chemical constituents identified in fraction 1are Heptadecanoic acid, heptadecyl ester $(8.64 \%)$ and (Z)-9-Octadecenoic acid [Oleic acid] (91.36 \%). Fraction 2 consists of Furo [2,3-c] pyridine, 2,3- 
dihydro-2 ,7-dimethyl- (0.90 \%), Hexadecanoic acid, methyl ester (8.28 \%), 3-Pyrrolidinol (0.58 \%), Hexadecanoic acid, ethyl ester (13.13\%), (Z)-6-Octadecenoic acid, methyl ester (21.01\%) and (E)-9Octadecenoic acid [Elaidic Acid] (56.10\%). Fraction 3 has (E)-9-Octadecenoic acid [Elaidic Acid] $(14.78 \%)$, 2-Ethylacridine (9.79 \%), (Z)-6-Octadecenoic acid [Petroselinic acid] (41.19\%) and trans13-Octadecenoic acid, methyl ester (29.34\%) and 2,3-Dihydroxypropyl (E)-9-Octadecenoate (4.89 $\%$ ) while fraction 4 consists of Hexadecanoic acid, methyl ester (17.89\%), Hexadecanoic acid, ethyl ester (21.33\%), (Z)-9-Octadecenoic acid, methyl ester (18.56\%) and (E)-9-Octadecenoic acid [Elaidic acid] (42.20\%).

GC-MS chromatograms of the peak of the compounds detected in fractions 1-4 were shown in Figures $1,2,3$ and 4 respectively. The identification of the phytochemical compounds was confirmed based on the peak area, retention time and molecular formula. The active principles with their Retention time (RT), Molecular formula, Molecular weight (MW) and peak area in percentage are presented in Tables $2 \& 3$. The phytochemicals identified through GC-MS analysis showed many biological activities relevant to this study are listed in Table 3. The biological activities listed are based on Dr. Duke's Phytochemical and Ethnobotanical Databases created by Dr. Jim Duke of the Agricultural Research Service/USDA.

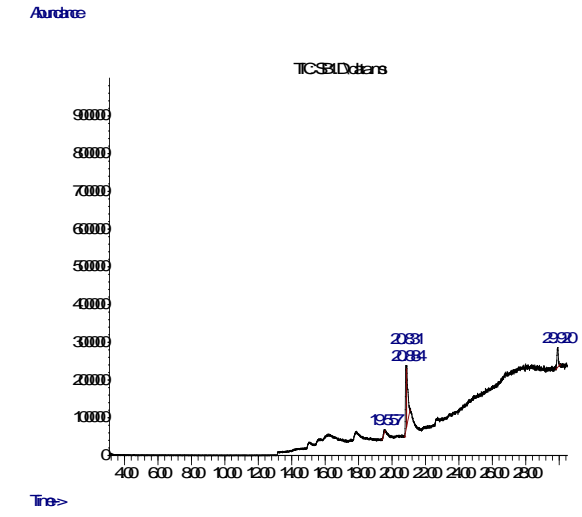

Figure1. GC-MS Chromatogram of fraction 1 of methanolic wood bark extract of D. zibethinus

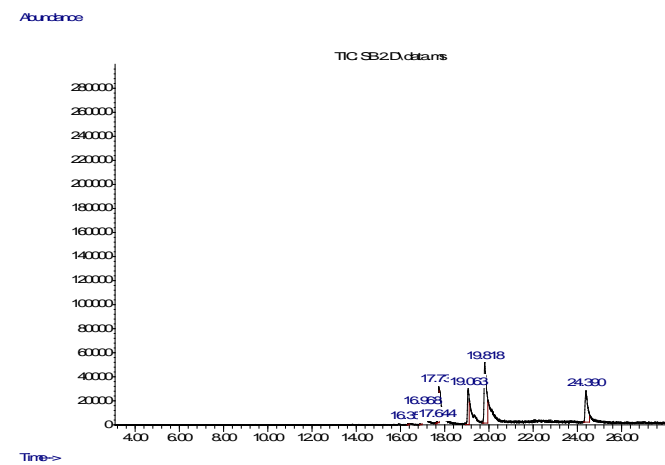

Figure2. GC-MS Chromatogram of fraction 2 of methanolic wood bark extract of D. zibethinus

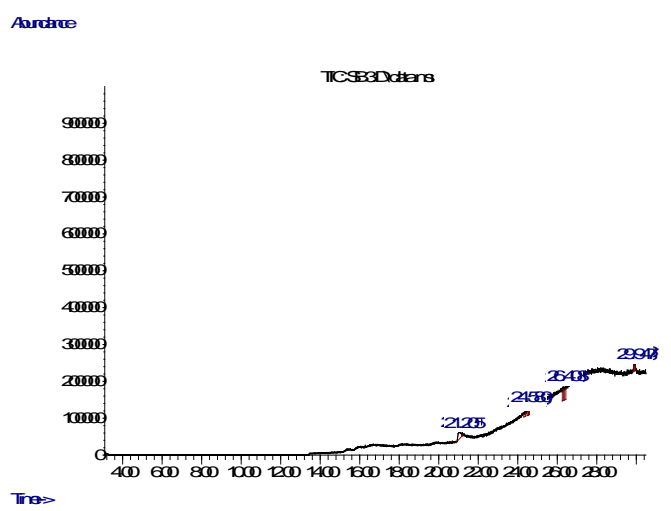

Figure3. GC-MS Chromatogram of fraction 3 of methanolic wood bark extract of D. zibethinus 
GC-MS Analysis of Phytochemical Constituents in Methanol Extract of Wood Bark from Durio Zibethinus Murr

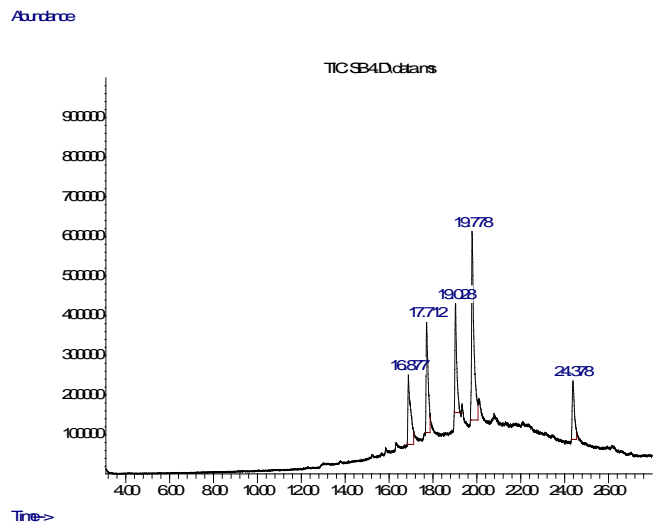

Figure4. GC-MS Chromatogram of fraction 4 of methanolic wood bark extract of D. zibethinus

Table2. GC-MS analysis revealed the presence of phytochemical compounds in methanol wood bark extract of D. zibethinus

\begin{tabular}{|c|c|c|c|c|c|}
\hline $\mathbf{S} / \mathbf{N}$ & $\mathbf{R} / \mathbf{T}$ & Name of Compound & $\begin{array}{l}\text { Molecular } \\
\text { Formular }\end{array}$ & $\begin{array}{l}\text { Molecular } \\
\text { Weight }\end{array}$ & $\begin{array}{l}\text { Peak } \\
\text { Area } \\
\%\end{array}$ \\
\hline \multicolumn{6}{|c|}{ Fraction 1} \\
\hline 1 & 19.557 & Heptadecanoic acid, heptadecyl ester & $\mathrm{C}_{34} \mathrm{H}_{68} \mathrm{O}_{2}$ & 508 & 8.64 \\
\hline 2 & 29.923 & (Z)-9-Octadecenoic acid (Oleic Acid) & $\mathrm{C}_{18} \mathrm{H}_{34} \mathrm{O}_{2}$ & 282 & 91.36 \\
\hline \multicolumn{6}{|c|}{ Fraction 2} \\
\hline 3 & 16.356 & Furo [2,3-c] pyridine, 2,3-dihydro-2,7-dimethyl- & $\mathrm{C}_{9} \mathrm{H}_{11} \mathrm{NO}$ & 149 & 0.90 \\
\hline 4 & 16.968 & Hexadecanoic acid, methyl ester & $\mathrm{C}_{17} \mathrm{H}_{34} \mathrm{O}_{2}$ & 270 & 8.28 \\
\hline 5 & 17.644 & 3-Pyrrolidinol & $\mathrm{C}_{4} \mathrm{H}_{9} \mathrm{NO}$ & 87 & 0.58 \\
\hline 6 & 17.730 & Hexadecanoic acid, ethyl ester & $\mathrm{C}_{18} \mathrm{H}_{36} \mathrm{O}_{2}$ & 284 & 13.13 \\
\hline 7 & 19.063 & (Z)-6-Octadecenoic acid, methyl ester & $\mathrm{C}_{19} \mathrm{H}_{36} \mathrm{O}_{2}$ & 296 & 21.01 \\
\hline 8 & 19.818 & (E)-9-Octadecenoic acid (Elaidic Acid) & $\mathrm{C}_{18} \mathrm{H}_{34} \mathrm{O}_{2}$ & 282 & 56.10 \\
\hline \multicolumn{6}{|c|}{ Fraction 3} \\
\hline 9 & 24.527 & (E)-9-Octadecenoic acid (Elaidic Acid) & $\mathrm{C}_{18} \mathrm{H}_{34} \mathrm{O}_{2}$ & 282 & 14.78 \\
\hline 10 & 24.579 & 2-Ethylacridine & $\mathrm{C}_{15} \mathrm{H}_{13} \mathrm{~N}$ & 207 & 9.79 \\
\hline 11 & 26.307 & (Z)-6-Octadecenoic acid (Petroselinic acid) & $\mathrm{C}_{18} \mathrm{H}_{34} \mathrm{O}_{2}$ & 282 & 41.19 \\
\hline 12 & 26.410 & trans-13-Octadecenoic acid, methyl ester & $\mathrm{C}_{19} \mathrm{H}_{36} \mathrm{O}_{2}$ & 296 & 29.34 \\
\hline 13 & 29.946 & 2,3-Dihydroxypropyl (E)-9-Octadecenoate & $\mathrm{C}_{21} \mathrm{H}_{40} \mathrm{O}_{5}$ & 373 & 4.89 \\
\hline \multicolumn{6}{|c|}{ Fraction 4} \\
\hline 14 & 16.877 & Hexadecanoic acid, methyl ester & $\mathrm{C}_{17} \mathrm{H}_{34} \mathrm{O}_{2}$ & 270 & 17.89 \\
\hline 15 & 17.712 & Hexadecanoic acid, ethyl ester & $\mathrm{C}_{18} \mathrm{H}_{36} \mathrm{O}_{2}$ & 284 & 21.33 \\
\hline 16 & 19.028 & (Z)-9-Octadecenoic acid, methyl ester & $\mathrm{C}_{19} \mathrm{H}_{36} \mathrm{O}_{2}$ & 296 & 18.56 \\
\hline 17 & 19.778 & (E)-9-Octadecenoic acid (Elaidic Acid) & $\mathrm{C}_{18} \mathrm{H}_{34} \mathrm{O}_{2}$ & 282 & 42.20 \\
\hline
\end{tabular}

Table3. GC-MS analysis showed phytochemical compounds, their nature and their biological activitie methanol wood bark extract of $D$. zibethinus

\begin{tabular}{|l|l|l|l|l|l|}
\hline S/N & R/T & $\begin{array}{l}\text { Peak } \\
\text { Area } \\
\%\end{array}$ & Name of Compound & $\begin{array}{l}\text { Compound } \\
\text { Nature }\end{array}$ & Activity \\
\hline Fraction 1 & 19.557 & 8.64 & Heptadecanoic acid, heptadecyl ester & Fatty acid & $\begin{array}{l}\text { Acidifier, } \\
\text { arachidonic acidulant, } \\
\text { inhibitor, } \\
\text { acid- } \\
\text { inhibit } \\
\text { production of uric acid. }\end{array}$ \\
\hline 1 & 29.923 & 91.36 & (Z)-9-Octadecenoic acid (Oleic Acid) & Fatty acid & $\begin{array}{l}\text { Anticancer, Anemiagenic, } \\
\text { Insectifuge, Antiandrogenic, } \\
\text { Dermatitigenic. }\end{array}$ \\
\hline Fraction 2 & 16.356 & 0.90 & $\begin{array}{l}\text { Furo [2,3-c] pyridine, 2,3-dihydro-2,7- } \\
\text { dimethyl- }\end{array}$ & $\begin{array}{l}\text { Pyridine } \\
\text { derivative }\end{array}$ & $\begin{array}{l}\text { Use in } \\
\text { fragrances, Pharmaceuticals, } \\
\text { agrochemicals } \\
\text { and }\end{array}$ \\
\hline 3 & & & & flavor, \\
\hline
\end{tabular}


GC-MS Analysis of Phytochemical Constituents in Methanol Extract of Wood Bark from Durio Zibethinus Murr

\begin{tabular}{|c|c|c|c|c|c|}
\hline 4 & 16.968 & 8.28 & Hexadecanoic acid, methyl ester & $\begin{array}{l}\text { Fatty acid } \\
\text { ester }\end{array}$ & $\begin{array}{l}\text { Antioxidant, } \\
\text { hypocholesterolemic, } \\
\text { antiandrogenic, flavor, hemolytic, } \\
\text { nematicide, ralpha reductase inhibitor } \\
\text { 5-als }\end{array}$ \\
\hline 5 & 17.644 & 0.58 & 3-Pyrrolidinol & $\begin{array}{l}\text { Pyrrolidine } \\
\text { derivative }\end{array}$ & No activity reported \\
\hline 6 & 17.730 & 13.13 & Hexadecanoic acid, ethyl ester & $\begin{array}{l}\text { Fatty acid } \\
\text { ester }\end{array}$ & $\begin{array}{l}\text { Antioxidant, flavor, } \\
\text { hypocholesterolemic, } \\
\text { nematicide, pesticide, } \\
\text { lubricant, antiandrogenic, } \\
\text { hemolytic, 5-alpha reductase } \\
\text { inhibitor }\end{array}$ \\
\hline 7 & 19.063 & 21.01 & (Z)-6-Octadecenoic acid, methyl ester & $\begin{array}{l}\text { Fatty acid } \\
\text { ester }\end{array}$ & Antioxidant, Antimicrobial. \\
\hline 8 & 19.818 & 56.10 & (E)-9-Octadecenoic acid (Elaidic Acid) & Fatty acid & $\begin{array}{ll}\text { Acidifier, } & \text { acidulant, } \\
\text { anticancer, } & \text { antitumor, } \\
\text { arachidonic acid-inhibitor. }\end{array}$ \\
\hline \multicolumn{6}{|c|}{ Fraction 3} \\
\hline 9 & 24.527 & 14.78 & (E)-9-Octadecenoic acid (Elaidic Acid) & Fatty acid & $\begin{array}{ll}\text { Acidifier, } & \text { acidulant, } \\
\text { anticancer, } & \text { antitumor, } \\
\text { arachidonic acid-inhibitor. }\end{array}$ \\
\hline 10 & 24.579 & 9.79 & 2-Ethylacridine & $\begin{array}{l}\text { Heterocyclic } \\
\text { compound }\end{array}$ & No activity reported \\
\hline 11 & 26.307 & 41.19 & (Z)-6-Octadecenoic acid (Petroselinic acid) & Fatty acid & $\begin{array}{l}\text { Cancer } \\
\text { Insectifuge. }\end{array}$ \\
\hline 12 & 26.410 & 29.34 & trans-13-Octadecenoic acid, methyl ester & $\begin{array}{l}\text { Fatty acid } \\
\text { ester }\end{array}$ & $\begin{array}{l}\text { Acidifier, } \\
\text { arachidonic acid-inhibitor, } \\
\text { inhibit production of uric } \\
\text { acid. }\end{array}$ \\
\hline 13 & 29.946 & 4.89 & 2,3-Dihydroxypropyl (E)-9-Octadecenoate & $\begin{array}{l}\text { Fatty acid } \\
\text { ester }\end{array}$ & $\begin{array}{l}\text { Anticancer, } \\
\text { antitumor,ectoparasiticide, } \\
\text { edemagenic }\end{array}$ \\
\hline \multicolumn{6}{|c|}{ Fraction 4} \\
\hline 14 & 16.877 & 17.89 & Hexadecanoic acid, methyl ester & acid & $\begin{array}{l}\text { Antioxidant, } \\
\text { hypocholesterolemic, } \\
\text { antiandrogenic, flavor, hemolytic, } \\
\text { nematicide, } \\
\text { 5-alpha reductase inhibitor }\end{array}$ \\
\hline 15 & 17.712 & 21.33 & Hexadecanoic acid, ethyl ester & $\begin{array}{l}\text { Fatty acid } \\
\text { ester }\end{array}$ & $\begin{array}{l}\text { Antioxidant, flavor, } \\
\text { hypocholesterolemic, } \\
\text { nematicide, pesticide, } \\
\text { lubricant, antiandrogenic, } \\
\text { hemolytic, 5-alpha reductase } \\
\text { inhibitor }\end{array}$ \\
\hline 16 & 19.028 & 18.56 & (Z)-9-Octadecenoic acid, methyl ester & $\begin{array}{l}\text { Fatty acid } \\
\text { ester }\end{array}$ & $\begin{array}{l}\text { Acidifier, acidulant, } \\
\text { arachidonic acid-inhibitor, } \\
\text { increase zinc bioavailability. }\end{array}$ \\
\hline 17 & 19.778 & 42.20 & (E)-9-Octadecenoic acid (Elaidic Acid) & Fatty acid & $\begin{array}{ll}\text { Acidifier, } & \text { acidulant, } \\
\text { anticancer, } & \text { antitumor, } \\
\text { arachidonic acid-inhibitor. }\end{array}$ \\
\hline
\end{tabular}

**Source: Dr. Duke's Phytochemical and Ethnobotanical Databases

Most phytochemical constituents identified in D.zibethinus wood bark are fatty acids and fatty acid esters that contribute to the antioxidant, antimicrobial, antitumor, cancer-preventive, hypocholesterolemic, nematicide, pesticide, antiandrogenic, hemolytic, 5-alpha reductase inhibitor, lubricant and flavor activities. Hence, the wood bark of D.zibethinus Murr is worthy for further investigation on isolation of individual phytochemical constituents and toxicological aspects for the development of new lead of therapeutic interest. 


\section{CONCLUSION}

The wood bark of D.zibethinus contains many important phytochemical components such as alkaloids, saponins, tannins, flavonoids, terpenoids, glycosides and phenolic compounds. However, the presence of these phytochemicals in this plant suggests its vast pharmacological potentials. The GC-MS analysis of methanolic extract showed a number of medicinal active components. Meanwhile, further studies are needed to isolate the bioactive components in the plant. Hence, this study may be useful to explore the pharmacological and biosynthetic activity of D.zibethinus Murr further.

\section{REFERENCES}

[1] Acamovic, T. \& Brooker, J.D (2005). Biochemistry of plant secondary metabolites and their effects in animals. Proc. Nutr Soc., 64, 403-412.

[2] Agu, G.C., \& Thomas, B.T. (2012). Antibacterial Activities of Ethanol and Aqueous Extracts of Five Nigerian Medicinal Plants on Some Wound Pathogens. Nature and Science, 10(2),78-84.

[3] Ahmed, A. et al (2008). Effects of digoxin at low serum concentrations on mortality and hospitalization in heart failure: a propensity-matched study of the DIG trial. Int. J. Cardiol. 123, 138-146.

[4] Aiyelaagbe, O.O. \& Osamudiamen, M.P (2009) "Phytochemical Screening for Active Compounds in Mangifera indica Leaves from Ibadan", Oyo State 2(1): 11-13.

[5] Alasalvar, C., Grigor, J.M., Zhang, D.L., Quantick, P.C \& Shahidi, F (2001). Comparison of volatiles, phenolics, sugars, antioxidant vitamins, and sensory quality of different colored carrot varieties. J. Agric. Food Chem., 49, 1410-1416.

[6] Alves, T.M. et al. (2000) Biological screening of Brazillian medicinal plants. Memorias do Instituto Oswaldo Cru 95(3): 367-373.

[7] Ang, A.M.G., Nalda, C.M.D.R. \& Sabejon, S.E (2018) Brine Shrimp Lethality and Antioxidant Activity of the Leaf, Rind and Seed Ethanolic Extracts of Durio zibethinusL., Asian Journal of Biological and Life Sciences 7(3):106-111.

[8] Ansari, R.M (2016) Potential use of durian fruit (Durio zibenthinus Linn) as an adjunct to treat infertility in polycystic ovarian syndrome. J Integr Med 14:22-28.

[9] Ateufack, G., Mokam, E.C.M., Mbiantcha, M., Feudjio, R.B.D., David, N. \& Kamanyi, A. (2015). Gastroprotective and ulcer healing effects of Piptadeniastrumafricanumon experimentally induced gastric ulcers in rats. BMC Complement Altern Med. 15, 214. Doi: 10.1186/s12906-015-0713-5.

[10] Bautista, J.R., Duazo, N.O. \& Teves, F.G (2012) Crude methanolic extract activity from rinds and seeds of native durian (Durio zibethinus) against Escherichia coli and Staphylococcus aureus, African Journal of Microbiology Research 6(35):6483-6486.

[11] Bhore, S.J., Husin, N.A., Rahman, S. \& Karunakaran, R (2018) A review on the nutritional, medicinal, and genome attributes of Durian (Durio zibethinus L.), the King of fruits in Malaysia. Bioinformation 14(6): 265-270.

[12] Bielawski, K., Winnicka, K. \& Bielawska, A (2006). Inhibition of DNA topoisomerases I and II, and growth inhibition of breast cancer MCF-7 cells by ouabain, digoxin and proscillaridin A. Biol. Pharm. Bull. 29, 1493-1497.

[13] Brown, M.J (1997) Durio - A Bibliographic Review. International Plant Genetic Resources Institute (IPGRI) office for South Asia, New Delhi.

[14] Cantrell, C. L., Franzblau, S. G. \& Fischer, N. H (2001). Antimycobacterial Plant Terpenoids. Planta Med., 67, 685-694.

[15] Chahar, M. K., Sharma, N., Dobhal, M. P \& Joshi, Y. C. (2011). Flavonoids: A Versatile Source of Anticancer Drugs. Pharmacogn. Rev. 5(9), 1-12.

[16] Chansiripornchai P, Pongsamart S (2008) Treatment of Infected Open Wound on Two Dogs Using a Film Dressing of Polysaccharide Extracted from the Hulls of Durian (Durio zibethinus Murr.): case report, Thai J. Vet. Med 38(3):55-61.

[17] Cushnie, T. P. T \& Lamb, A. J (2005). Antimicrobial activity of flavonoids International Journal of Antimicrobial Agents; 26, 343-356.

[18] Cushnie, T. P. T., Cushnie, B. \& Lamb, A. J.( 2014) "Alkaloids: an overview of their antibacterial, antibiotic-enhancing and antivirulence activities," International Journal of Antimicrobial Agents, 44(5), 377-386.

[19] Daniel, D., Susal, C., Kopp, B., Opelz, G. \& Terness, P (2003). Apoptosis-mediated selective killing of malignant cells by cardiac steroids: maintenance of cytotoxicity and loss of cardiac activity of chemically modified derivatives. Int. Immunopharmacol. 3, 1791-1801. 
[20] Doherty, V.F., Olaniran, O.O. \& Kanife, U.C. (2010). Antimicrobial activities of Aframomum melegueta(Alligator pepper). International Journal of Biology, 2(2), 126 - 131.

[21] Doughari, J.H., Human, I.S., Bennade, S. \& Ndakidemi, P.A. (2009). Phytochemicals as chemotherapeutic agents and antioxidants: Possible solution to the control of antibiotic resistant verocytotoxin producing bacteria. Journal of Medicinal Plants Research, 3(11), 839-849.

[22] Edrah, S.M., Alfalluos, K.A., Alnade, H.S., Kollab, W.A.\& Alafid, F (2017) Qualitative and Quantitative phytochemical Analysis and Antimicrobial Activity of "Retama" Extract Grown in Zliten Libya, International Journal of Medical Science and Clinical Inventions 4(4): 2861-2866.

[23] Edreva, A., Velikova, V., Tsonev, T., Dagnon, S., Gürel, A.L \& Aktas, L (2008). Stress-protective role of secondary metabolites: Diversity of functions and mechanisms. Gen.Appl. Plant. Physiol., 34, 67-78.

[24] Ejikeme, C.M., Ezeonu, C.S. \& Eboatu, A.N (2014) "Determination of physical and Phytochemical constituents of some tropical timbers indigenous to Niger Delta Area of Nigeria," European Scientific Journal 10(18): 247-270.

[25] Epidi, J.O., Izah, S.C. \& Ohimain, E.I. (2016). Antibacterial and synergistic efficacy of extracts of Alstonia boonei tissues. British Journal of Applied Science, 1(1), 21 - 26.

[26] Foye, W.O, Lemke, T.L. \& Williams, D.A (2008) Foye's Principles of Medicinal Chemistry. 6th Ed Lippincott Williams and Wilkins. Philadelphiap 44-45.

[27] Frese, S. et al (2006). Cardiac glycosides initiate Apo2L/ TRAIL-induced apoptosis in non-small cell lung cancer cells by up-regulation of death receptors 4 and 5. Cancer Res. 66, 5867-5874.

[28] Gothandam, K.M., Aishwarya, R. \& Karthikeyan, S. (2010) Preliminary screening of antimicrobial properties of few medicinal plants. Journal of Phytology 2(4): 1-6.

[29] Gordon, M.C. \& David, J.N (2001) Natural product drug discovery in the next millennium.Pharm. Biol 39(1): 8-17.

[30] Haruenkit, R., Poovarodom, S., Kruszewska, H., Leontowicz, M., Sajewicz, M., Kowalska, T., Delgado, E., Rocha, N., Gallegos-Infante, J.A., Trakhtenberg, S. \&Gorinstein, S (2007). Comparative Study of Health Properties and Nutritional Value of Durian, Mangosteen, and Snake Fruit: Experiments In vitro and In vivo, J Agric Food Chem 55(14):5842-5849.

[31] Hazem, A., Fawzia, A.C \& Dina, G (2012). Biochemical, antibacterial and antifungal activity of extracts from Achillea fragrantissima and evaluation of volatile oil composition. Der Pharmacia Sinica. 3(3), 349356.

[32] Heima, K.E., Tagliaferroa, A.R. \& Bobilya, D.J (2002). Flavonoid antioxidants: Chemistry, metabolism and structure-activity relationships. J. Nutr. Biochem., 13, 572-584.

[33] Ho, L.H. \& Bhat, R (2015) Exploring the potential nutraceutical values of durian (Durio zibethinus L.) An exotic tropical fruit, Food Chem 168:80-89.

[34] Huang, Y. T., Chueh, S. C., Teng, C. M. \& Guh, J. H (2004). Investigation of ouabain- induced anticancer effect in human androgen-independent prostate cancer PC-3 cells. Biochem. Pharmacol. 67, 727-733.

[35] Jalil, A.M.M. \& Aziz, N.A.A (2019) Bioactive Compounds, Nutritional Value, and Potential Health Benefits of Indigenous Durian (Durio Zibethinus Murr.): A Review, Foods 8(3), 96.

[36] Khanbabaee, K. \& van Ree, T (2001). "Tannins: classification and definition," Natural Product Reports, 18(6), 641-649.

[37] Kigigha, L.T., Izah, S.C., \& Ehizibue, M. (2015). Activities of Aframomum melegueta Seed Against Escherichia coli, S. aureus and Bacillus species. Point Journal of Botany and Microbiology Research, 1(2), $23-29$.

[38] Kittakoop, P., Mahidol, C. \& Ruchirawat, S (2014). "Alkaloids as important scaffolds in therapeutic drugs for the treatments of cancer, tuberculosis, and smoking cessation," Current Topics in Medicinal Chemistry, 14(2), 239-252.

[39] Kometiani, P., Liu, L. \& Askari, A (2005). Digitalis-induced signaling by Na+/K+-ATPase in human breast cancer cells. Mol. Pharmacol. 67, 929-936.

[40] Kumar, E.K., Ramesh, A. \& Kasiviswanath, R (2005) Hypoglicemic and Antihyperglicemic Effect of Gmelina asiatica Linn. in Normal and in Alloxan Induced Diabetic Rats. Biol. Pharm. Bull 28(4): 729732 .

[41] Leontowicz, H., Leontowicz, M., Haruenkit, R., Poovarodom, S., Jastrzebski, Z., Drzewiecki, J., Ayala, M.L.A., Jesion, I., Trakhtenberg, S. \& Gorinstein, S (2008) Durian (Durio zibethinus Murr.) cultivars as nutritional supplementation to rat's diets, Food Chem. Toxicol 46:581-589. 
[42] Leontowicz, M., Leontowicz, H., Drzewiecki, J., Jastrzebski, Z., Haruenkit, R., Poovarodom, S., Park, Y.S., Kang, S.G., Trakhtenberg, S. \& Gorinstein S (2007) Twoexotic fruits positively affect rat's plasma composition, Food Chem 102(1):192-200.

[43] Lopez-Lazaro, M. et al (2005). Digitoxin inhibits the growth of cancer cell lines at concentrations commonly found in cardiac patients. J. Nat. Prod. 68, 1642-1645.

[44] McConkey, D. J., Lin, Y., Nutt, L. K., Ozel, H. Z. \& Newman, R. A (2000). Cardiac glycosides stimulate $\mathrm{Ca} 2+$ increases and apoptosis in androgen-independent, metastatic human prostate adenocarcinoma cells. Cancer Res., 60, 3807-3812.

[45] Mijatovic, T. et al (2006). The cardenolide UNBS1450 is able to deactivate nuclear factor KB-mediated cytoprotective effects in human non-small cell lung cancer cells. Mol. Cancer Ther. 5, 391-399.

[46] Newman, R. A. et al (2006). Oleandrin-mediated oxidative stress in human melanoma cells. J. Exp. Ther. Oncol. 5, 167-181.

[47] Newman, R. A. et al (2007). Autophagic cell death of human pancreatic tumor cells mediated by oleandrin, a lipid-soluble cardiac glycoside. Integr. Cancer Ther. 6, 354-364.

[48] Okuda, T. (2005). Systematics and health effects of chemically distinct tannins in medicinal plants. Phytochemistry, 66(17), 2012-2031.

[49] Okwu, D.E. \& Okwu, M.E. (2004). Chemical composition of Spondias mombia Linn plant parts. Journal of Sustain Agricultural Environment, 6, 140-147.

[50] Okwu, D.E. (2005). Phytochemicals, Vitamins and Mineral contents of two Nigeria Medicinal Plants. International Journal of Molecular Medicine and Advance Sciences, 1(4), 375-381.

[51] Osuntokun,O.T. \& Oluwafoise, B.O. (2015). Phytochemical screening of ten Nigerian medicinal plants. International Journal of Multidisplinary Research and Development, 2(4), 390-396.

[52] Patel, P.P \& Patil, P.H. (2012). Anti-inflammatory activity of saponin rich fraction isolated from the Thespesia populnea (L.) leaves. Intl J Biomed Pharma Sci. 3(4),1526-1532.

[53] Prabhavathi, R.M., Prasad, M.P, Jayaramu, M. (2016) Studies on Qualitative and Quantitative Phytochemical Analysis of Cissus quadrangularis, Advances in Applied Science Research 7(4):11-17.

[54] Qiu, S., Sun, H., Zhang, A. H. et al. (2014). "Natural alkaloids: basic aspects, biological roles, and future perspectives," Chinese Journal of Natural Medicines, 12(6), 401-406.

[55] Raghavendra, P. B., Sreenivasan, Y., Ramesh, G. T. \& Manna, S. K (2007). Cardiac

glycoside induces cell death via FasL by activating calcineurin and NF-AT, but apoptosis initially proceeds through activation of caspases. Apoptosis, 12, 307-318.

[56] Rahman, G., Syed, U.J., Syed, F., Samiullah, S., Nusrat, J. (2017) Preliminary Phytochemical Screening, Quantitative Analysis of Alkaloids, and Antioxidant Activity of Crude Plant Extracts from Ephedra intermedia Indigenous to Balochistan, The Scientific World Journal vol. 2017, Article ID 5873648, pp: 17.

[57] Rajic, A., Kweifio-Okai, G., Macrides, T., Sandeman, R. M., Chandler, D. S. \& Polya, G. M (2000). Inhibition of Serine Proteases by Anti-Inflammatory Triterpenoids. Planta Med., 66, 206-210.

[58] Sanjeeb, K., Guarav, K., Karthik, L. \& Bhaskar R (2011). Phytochemical Composition and In Vitro Hemolytic Activity of Lantana Camara L. (Verbenaceae) Leaves, Pharmacologyonline 1:59-67.

[59] Santhi, K. \& Sengottuvel, R. (2016) Qualitative and Quantitative Phytochemical analysis of Moringa concanensis Nimmo, Int.J.Curr.Microbiol.App.Sci 5(1): 633-640.

[60] Seema, F. \& Parwez, A. (2011) "Phytochemical investigation of extract of Amorphophallus campanulatus tubers", International Journal of Phytomedicine vol.3, pp.32-35.

[61] Siburian, R., Aruan, D.G.R., Barus, T., Haro, G. \& Simanjuntak, P. (2019). Phytochemical Screening and Antidiabetic Activity of N-hexane, Ethyl acetate and Water Extract from Durian Leaves (Durio zibethinus L.), Oriental Journal of Chemistry 35(1):487-490.

[62] Soetan, K.O, Oyekunle, M.A, Aiyelaagbe, O.O. \& Fafunso, M.A (2006). Evaluation of the antimicrobial activity of saponins extract of Sorghum Bicolor L. Moench. Afr J. Biotechnol. 5, 2405-2407.

[63] Subhadrabandhu, S. \& Ketsa, S (2001). Durian-king of tropical fruit. Throdon, Wellington, New Zealand: Daphne Brasell Associates. pp. 66-69.

[64] Sweetman, S.C (2005). Martindale In The Complete Drug Reference. Pharmaceutical Press, Williams Clowes; Suffock, UK. p. 907.

[65] Villar, A.M., de las Heras B., Rodríguez, B. \& Boscá, L (2003). Terpenoids: Sources, Structure Elucidation and Therapeutic Potential in Inflammation, Current Topics in Medicinal Chemistry, 3, 53-67 
[66] Yamamoto, Y \& Gaynor, R.B (2001). Therapeutic potential of inhibition of the NF kappa B pathway in the treatment of inflammation and Cancer. J.Clin Invest; 107(2), 135-142.

[67] Yao, W. R., Wang, H. Y., Wang, S. T., Sun, S. L., Zhou, J \& Luan, Y. Y. (2011).Assessment of the Antibacterial Activity and the Antidiarrheal Function of Flavonoids from Bayberry Fruit. J. Agric. Food Chem. 59(10), 5312-5317.

[68] Yeh, J. Y., Huang, W. J., Kan, S. F. \& Wang, P. S (2003). Effects of bufalin and cinobufagin on the proliferation of androgen dependent and independent prostate cancer cells. Prostate 54, 112-124.

Citation: Adeniyi S Adegoke, et.al.,(2019). GC-MS Analysis of Phytochemical Constituents in Methanol Extract of Wood Bark from Durio Zibethinus Murr. International Journal of Medicinal Plants and Natural Products (IJMPNP), 5(3), pp.1-11. http://dx.doi.org/10.20431 /2454-7999.0503001

Copyright: (C) 2019 Authors, This is an open-access article distributed under the terms of the Creative Commons Attribution License, which permits unrestricted use, distribution, and reproduction in any medium, provided the original author and source are credited. 